\title{
Practice of contraceptives
}

\author{
S Pandey, ${ }^{1}$ S Karki, ${ }^{2}$ A Pradhan ${ }^{1}$ \\ ${ }^{1}$ Department of Community Medicine, KIST Medical College, Imadol, Lalitpur, Nepal; ${ }^{2}$ Hetauda School of Management \\ and Social Sciences, Hetauda, Nepal
}

Correspondence to: Srijana Pandey, Department of Community Medicine, KIST Medical College, Imadol, Lalitpur, Nepal, Phone: 977-1-5-201680 (Office), 977-01-4-473875 (Res.), 98510-86235 (Mob.)

Email: sirupandey@gmail.com

\begin{abstract}
Introduction: Over the past decades fertility rate have surprisingly been stagnated demanding further research on the ways it reduces rate to a level appropriate for healthy population. Considering the status of male in developing countries like Nepal, it is believed that men play vital role in achieving success in this sector. Therefore this study was done to find out the knowledge and practice of contraceptives among married males of Makwanpur, Nepal.
\end{abstract}

Methods: This is a cross-sectional descriptive study. Data were collected from the 387 respondents by personal interview using semi-structured questionnaire.

Results: Mean age of the respondents was 34.48 years. Most of the respondents knew at least four contraceptive methods. There is a strong relationship between knowledge and the use of contraceptives with the level of education and economic status having a direct impact. The attitude of male respondents to share responsibility for promotion of contraceptive was found to be positive.

Conclusions: Almost majority agree that the responsibility for contraception should shared by both partner, but use of contraceptive methods among men is still low. This study recommended in depth action research to promote male contraceptive methods and priority for service delivery program in Nepal.

Keywords: Contraceptives, family planning, knowledge and practice of contraceptives

\section{Introduction}

Amongst the various challenges faced by human beings, the most important one today is not infectious disease but population. Over time, family planning program has been changed considerably. Currently, $63 \%$ of women in developing countries use a method of family planning. ${ }^{1}$ Family planning programs in the past had focused mainly on women for several reasons. Women bear the risk and burden of pregnancy, they are mainly involved in rearing them, and hence, it must have been assumed that women have greatest stake and interest in protecting their own reproductive health. ${ }^{2}$ But in reality, males dominate the society and many women can do little to protect themselves from unwanted pregnancy and unsafe sex. About one in six married women still has an unmet need for family planningthat is she wants to postpone her next pregnancy or stop having children altogether but, for whatever reason, is not using contraception. ${ }^{3}$ As a result, each year 76 million women in developing countries still bump into unintended pregnancies and 19 million resort to unsafe abortions. ${ }^{4,5}$ Many married women who want to avoid pregnancies are not using contraception because of their husbands objection to it. In Demography Health Survey, that $99 \%$ of 
married women still has unmet need of family planning points out husbands' disapproval as principal reasons for their not using contraception. ${ }^{6}$

Thus, using hoarding boards depicting contraceptive methods for men to promote their participation and increase their responsibility is a priority for the services delivery program and for contraceptive research and development activities. It needs to be recognized that women, particularly in developing economies, are often economically and emotionally dependent on their male partners. The need to encourage and enable men to take responsibility for their sexual and reproductive behavior and their social and family roles was also stressed during the International Conference on Population and Development 1994 Cairo. ${ }^{7}$ The behavioral and psychosocial aspects of reproductive health issues concerning men revolve around their involvement in contraceptive programs.

Considering population explosion an important issue, the government of Nepal has made family planning services an integral part of health service and developed the concepts of anti-natalist or small family norm as two children per couple. Advocating and motivating for family planning has been considered a basic human right. This program is running smoothly and achieving considerable success. The contraceptive prevalence rate in eligible Nepali couples has become $40.69 \%$ in $2004 .{ }^{8}$ In spite of tremendous achievement in the use of contraceptive among Nepalese, low utilization of male contraceptive methods still remains a major drawback in the world as well as Nepal. Male involvement in using contraceptives is only $10.2 \%$ against a total of $40.69 \% .{ }^{8}$ This shows their lack of motivation to adopt contraceptive methods in practical life. Apparently, it is the contribution of female that has made some advancement in family planning over the years; involvement of men also can lead to significant progress in the future. Besides being cheap and less hazardous compared to female methods, male contraceptives also help a lead healthy life by preventing sexually transmitted diseases. In addition, vasectomy is a simpler, faster and less expensive operation than tubectomy. The cost ratio is about five vasectomies to one tubal ligation. ${ }^{9}$ Therefore, increase in use of male contraceptive methods will contribute not only to limit the family size but also to develop a healthy nation.

As the population policy of Nepal is aiming for a drastic reduction in fertility in order to achieve the demography goals, there is no option but to further increase the contraceptive prevalence rate to about $58.2 \%$ for which male involvement is still warranted. ${ }^{10}$ As the coverage of family planning program has been increasing, its success can also be attributed to increase in male acceptance but increasing their participation will further contribute to the cause. A study in this field will help to strengthen national birth control programs by assessing the present status and promoting motivational programs to increase male participation for reducing the population growth.

\section{Methods}

The main objective of this study was to explore the knowledge and practice of contraceptive methods among married males. Our study also intended to find out sociodemographic characteristics of the respondents; assess knowledge of respondents on contraceptive methods; investigate the association between knowledge and use of contraceptive methods; examine the association between socio-demographic factors and use of contraceptive methods among males and analyze the association between exposure to mass media and use of contraceptives.

This is a cross-sectional descriptive study conducted in Hatiya VDC of Makawanpur. The ultimate sample size was 387 which was determined by using the formula $\mathrm{n}=\mathrm{Z}^{2} \mathrm{pq} / \mathrm{d}^{2}$

A semi-structured questionnaire was administered to interview the purposively selected 387 married males, whose wives were in the reproductive age group. Age, religion, occupation, education, total monthly income and the number of living children in the family that are often associated with contraceptive behaviors were noted. Additionally, respondents were asked specifically whether they had any knowledge on contraceptive methods. All the collected data were then analyzed by SPSS 13.0. Results were obtained by the frequency distribution and cross tabulation of the variables. Cross-tabulation and association were determined using chi-square test.

Couples from Hatiya V.D.C., Makawanpur with the female in reproductive age (15-49 yrs) were included in the study. Couples with primary/secondary infertility or divorced and one of the partners mentally retarded, handicapped or seriously ill were excluded from the study.

\section{Results}

387 married men were interviewed to find out the level of knowledge and practice of contraceptives methods.

Socio-demographic characteristics: Common and major aspects of socio-demographic perspectives such as age distribution, caste/ethnicity, religion, educational status occupation, family income, number of children are enumerated (Table 1). 
Table 1: Socio-demographic characteristics of the respondents

\begin{tabular}{|c|c|}
\hline $\begin{array}{l}\text { Socio-demographic } \\
\text { Variables }\end{array}$ & Number $(\%)$ \\
\hline $\begin{array}{l}\text { Age } \\
21-30 \text { years } \\
31-40 \text { years } \\
41-49 \text { years }\end{array}$ & $\begin{array}{l}127(32.8) \\
197(50.9) \\
63(16.3) \\
\text { Mean age 33.48, SD } \quad 6.164\end{array}$ \\
\hline$\underline{\text { Religion }}$ & \\
\hline $\begin{array}{l}\text { Hindu } \\
\text { Islam } \\
\text { Buddhist } \\
\text { Christian }\end{array}$ & $\begin{array}{l}337(87.1) \\
2(0.5) \\
39(10.1) \\
9(2.3)\end{array}$ \\
\hline $\begin{array}{l}\text { Education status } \\
\text { of the respondents }\end{array}$ & \\
\hline $\begin{array}{l}\text { Illiterate } \\
\text { Literate } \\
\text { SLC } \\
\text { Intermediate and above } \\
\text { Education status of } \\
\text { respondent wife }\end{array}$ & $\begin{array}{l}83(21.4) \\
94(24.3) \\
133(34.4) \\
77(19.9)\end{array}$ \\
\hline $\begin{array}{l}\text { Illiterate } \\
\text { Literate } \\
\text { SLC } \\
\text { Intermediate and above }\end{array}$ & $\begin{array}{l}129(33.3) \\
227(58.7) \\
29(7.5) \\
2(0.5)\end{array}$ \\
\hline Occupation & \\
\hline $\begin{array}{l}\text { Government service } \\
\text { Farmer } \\
\text { Foreign Employee } \\
\text { Private job } \\
\text { Businessmen }\end{array}$ & $\begin{array}{l}71(18.3) \\
200(51.7) \\
5(1.3) \\
94(24.3) \\
17(4.4)\end{array}$ \\
\hline Family Income & \\
\hline $\begin{array}{l}\text { Less than Rs. } 2000 \\
\text { Rs. } 2001-3000 \\
\text { Rs.3001-4000 } \\
\text { Rs. 4001above }\end{array}$ & $\begin{array}{l}174(45) \\
106(27.4) \\
60(15.5) \\
47(12.1) \\
\text { Mean income 2761.24, } \\
\text { range, 1100-20000 }\end{array}$ \\
\hline$\underline{\text { Number of live children }}$ & \\
\hline $\begin{array}{l}\text { Below } 2 \text { children } \\
3-4 \text { children } \\
5-6 \text { children }\end{array}$ & $\begin{array}{l}207(53.5) \\
141(36.4) \\
39(10.1)\end{array}$ \\
\hline
\end{tabular}

$(\mathrm{N}=387)$

Responsibility for contraception: Majority of the respondents want to share responsibility among them (Fig. 1). Of the total respondents, $55.8 \%$ mentioned that responsibility for contraception should be shared by both husband and wife, $28.2 \%$ mentioned it to be wife's responsibility while $16 \%$ agreed on their own responsibility.

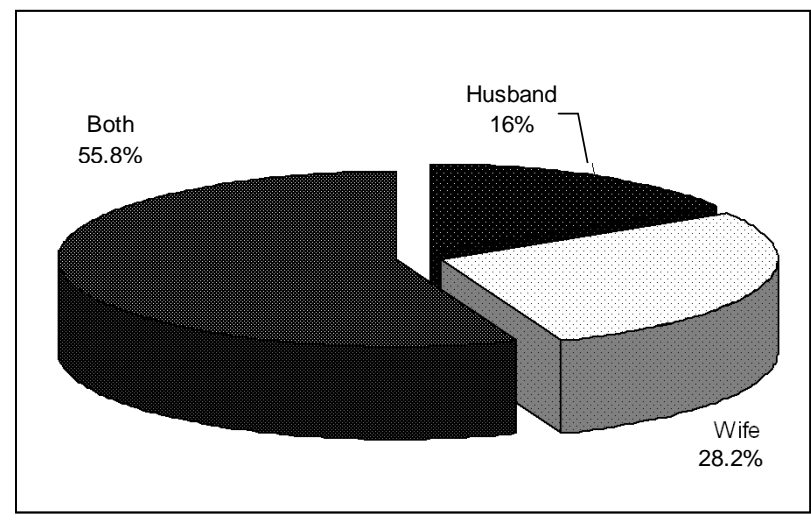

Fig. 1: Responsibility for contraception

Contraceptive practices by respondents : Current use of contraception is defined as the proportion of men who reported they were using contraceptive methods at the time of interview. Of 387 respondents, only 56(14.5\%) were using condoms or vasectomy for contraception in practical life (Table 2); 39(69.6\%) had vasectomy while $17(30.4 \%$ ) were using condoms. 187(48.3\%) respondents had used condom as contraceptive at least once but 144(37.2\%) had never used them. Similarly, $80.2 \%$ of the respondents collected contraceptive methods from government hospitals, $60.9 \%$ collected from private medicals and 5.9\% respondents collected from general stores.

Table 2: Contraceptive practices of the respondents

\begin{tabular}{|c|c|}
\hline $\begin{array}{l}\text { Use of contraceptive } \\
\text { by respondents }\end{array}$ & Number $(\%)$ \\
\hline Currently using contraceptive methods & $56(14.5)$ \\
\hline Vasectomy & $39(69.6)$ \\
\hline Condom & $17(30.4)$ \\
\hline \multicolumn{2}{|l|}{ Currently using contraceptive methods } \\
\hline Ever used & $187(48.3)$ \\
\hline Never used & $144(37.2)$ \\
\hline \multicolumn{2}{|l|}{ Source of contraceptive methods collection } \\
\hline Health center and Hospital & 195(80.2) \\
\hline Private medical & $148(60.9)$ \\
\hline General store & $58(5.9)$ \\
\hline
\end{tabular}

Reasons for not using contraceptives: The respondents never using any contraceptive were 144 (Fig. 2). They responded that their female partners used contraceptives $125(86.8 \%)$, whereas $12(8.3 \%)$ of them followed natural method. Many respondents $65(45.1 \%)$ mentioned that male 
contraceptives interfered with sexual satisfaction. Similarly, $55(38.2 \%)$ respondents wanted alternative methods, $41(28.5 \%)$ did not use due to health concerns and 33(22.9\%) respondents wanted to extend their family.

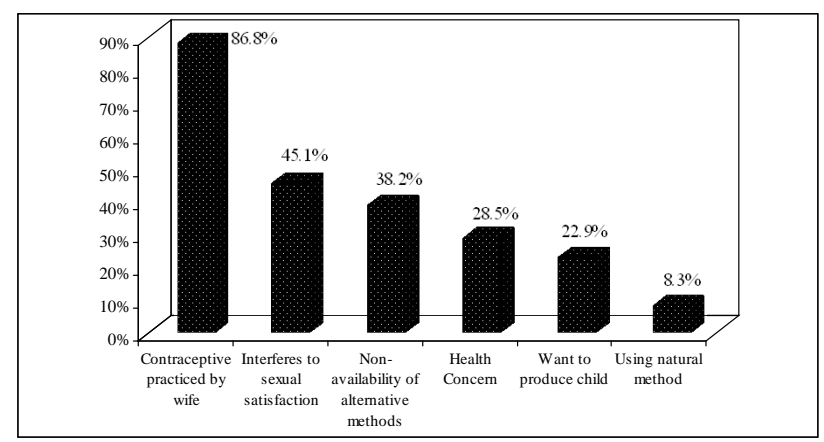

* Multiple responses

Fig. 2: Reasons for not using contraceptive methods $\left(\mathrm{N}=144^{*}\right)$

Knowledge on the contraceptive methods : Knowledge of at least one method of family planning is nearly universal in this study. Regarding contraceptive methods, most of the respondents had knowledge about condom i.e., 99\%, followed by oral pill $97.4 \%$ (Fig. 3).

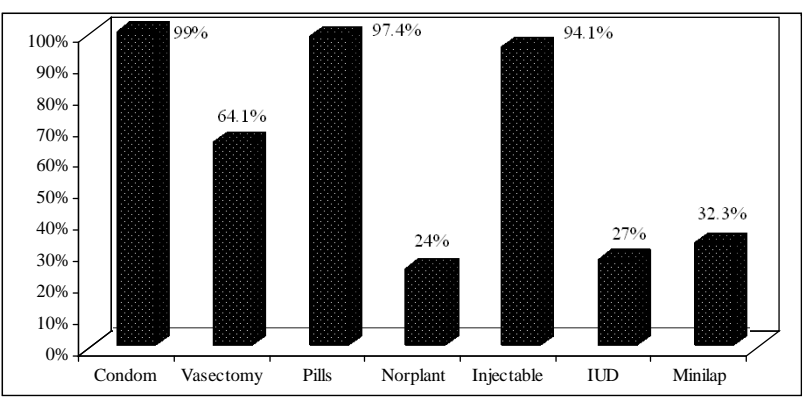

Fig. 3: Respondents who knew about contraceptive methods

Regarding the side effects of female contraceptive methods, $77 \%$ of the respondents had headache followed by bleeding. Regarding the knowledge of advantages of condom, $93.5 \%$ knew it prevented from sexual transmitted diseases; $91.5 \%$ knew it prevented from conception and $19.5 \%$ answered that it had lesser side effects (Table 3). Few (34.1\%) of the respondents had poor knowledge and could only mention a few (2-3) names of contraceptive methods. Majority $(50.9 \%)$ of the respondents had moderate knowledge. Similarly, $15 \%$ of the respondents had good knowledge that they mentioned names, advantages and disadvantages of the contraceptive methods. Among the respondents having good knowledge, $62.2 \%$ were using the contraceptive methods. Similarly, among those having moderate knowledge, $30.4 \%$ respondents were using contraceptive methods and those having poor knowledge, $7.1 \%$ of the respondents were using the contraceptive methods (Table 4).

Table 3: Respondents who knew about any side effect of female contraceptive methods and merits of condom

$\begin{array}{ll}\begin{array}{l}\text { Side effects of female } \\ \text { contraceptive methods }\end{array} & \text { Frequency(\%) } \\ \text { Headache } & 298(77) \\ \text { Nausea } & 43(11.1) \\ \text { High blood pressure } & 19(4.9) \\ \text { Bleeding } & 133(34.4) \\ \text { Merits of Condom } & \\ \text { Fewer side effects } & 77(19.9) \\ \text { Prevents from conception } & 354(91.5) \\ \text { Prevents from STD } & 362(93.5)\end{array}$

$\mathrm{N}=387$

Table 4: Relationship of respondents by current contraceptive use and level of knowledge

\begin{tabular}{|c|c|c|c|c|}
\hline $\begin{array}{l}\text { Level of } \\
\text { Knowledge }\end{array}$ & $\begin{array}{l}\text { Current } \\
\text { Contrace } \\
\text { Current } \\
\text { users } \\
(\mathrm{n}=56)\end{array}$ & $\begin{array}{l}\text { Use of } \\
\text { ptive } \\
\text { Non } \\
(\mathrm{n}=331) \\
\text { users }\end{array}$ & $\begin{array}{l}\text { Total } \\
(n=387)\end{array}$ & p Value \\
\hline & $\mathbf{N}(\%)$ & $\mathbf{N}(\%)$ & $\mathrm{N}(\%)$ & 0.0001 \\
\hline $\begin{array}{l}\text { Poor knowledge } \\
\text { Moderate }\end{array}$ & $4(7.1)$ & $128(38.7)$ & $132(34.1)$ & \\
\hline $\begin{array}{l}\text { Knowledge } \\
\text { Good }\end{array}$ & $17(30.4)$ & $180(54.4)$ & $197(50.9)$ & \\
\hline Knowledge & $35(62.2)$ & $23(6.9)$ & $58(15.0)$ & \\
\hline
\end{tabular}

Association between socio-demographic variables and current use of contraceptive methods: Among the contraceptive users, $50 \%$ of respondents between 31-40 years age group were currently using contraceptive. Similarly, $26.8 \%$ of respondents among the age group 41-49 years and within the age group 21-30 years only $23.2 \%$ were using it.

Among them, $83.9 \%$ of those using contraceptives were Hindus where as $16.1 \%$ were following Islam, Buddhism and Christianity.

It is seen that $89.3 \%$ of respondents who passed school leaving certificate (SLC) and had formal education were currently using contraceptives. Likewise, $7.1 \%$ of the literate and $3.6 \%$ of the Illiterate respondents were currently using contraceptive.

In terms of educational status, $33.3 \%$ of the respondents' 
wives were illiterate whereas $58.7 \%$ were literate. Similarly, $7.5 \%$ had passed the 'School leaving certificate' and 5\% had completed intermediate level of education. Of the respondents using contraceptives, $60.7 \%$ had literate wife. Similarly, $28.6 \%$ of those whose wife had passed SLC and had formal education were using contraceptive and only $10.7 \%$ of the respondents who had an illiterate wife were using contraceptive $(\mathrm{p}<0.001)$.

Most (51.7\%) of the respondents were farmers, $18.3 \%$ were government employees, $24.3 \%$ held private jobs and only $1.3 \%$ was under foreign employment. Most of the respondents who were engaged in private jobs were using contraceptive followed by government employee (Table 5).

Nepal is a very poor country with per capita income less than \$500. Majority of the respondents (45\%) had income less than Rs. 2000 per month; $27.4 \%$ respondents earned Rs. 2001-3000 and 15.5\% earned Rs. 3001-4000. Very few $(12.1 \%)$ respondents earned more than Rs. 4000 per month. In our study, it was found that $53.6 \%$ of the respondents having monthly income more than Rs. 4000 were currently using contraceptives. Likewise, $37.5 \%$ having monthly income of Rs. 3100-4000 and 5.4\% having monthly income of Rs. 2100-3000 were using contraceptives.

Most of the respondents (53.5\%) had less than two children, $36.4 \%$ had 3-4 children and $10.1 \%$ had 5-6 children. Among the respondents having less than two children, $53.6 \%$ were using contraceptive methods (Table 5) and $32.1 \%$ amongst those having 3-4 children but the association between use of contraceptive and number of live children was not significant.

Table 5: Association between socio-demographic variables and current use of contraceptive methods

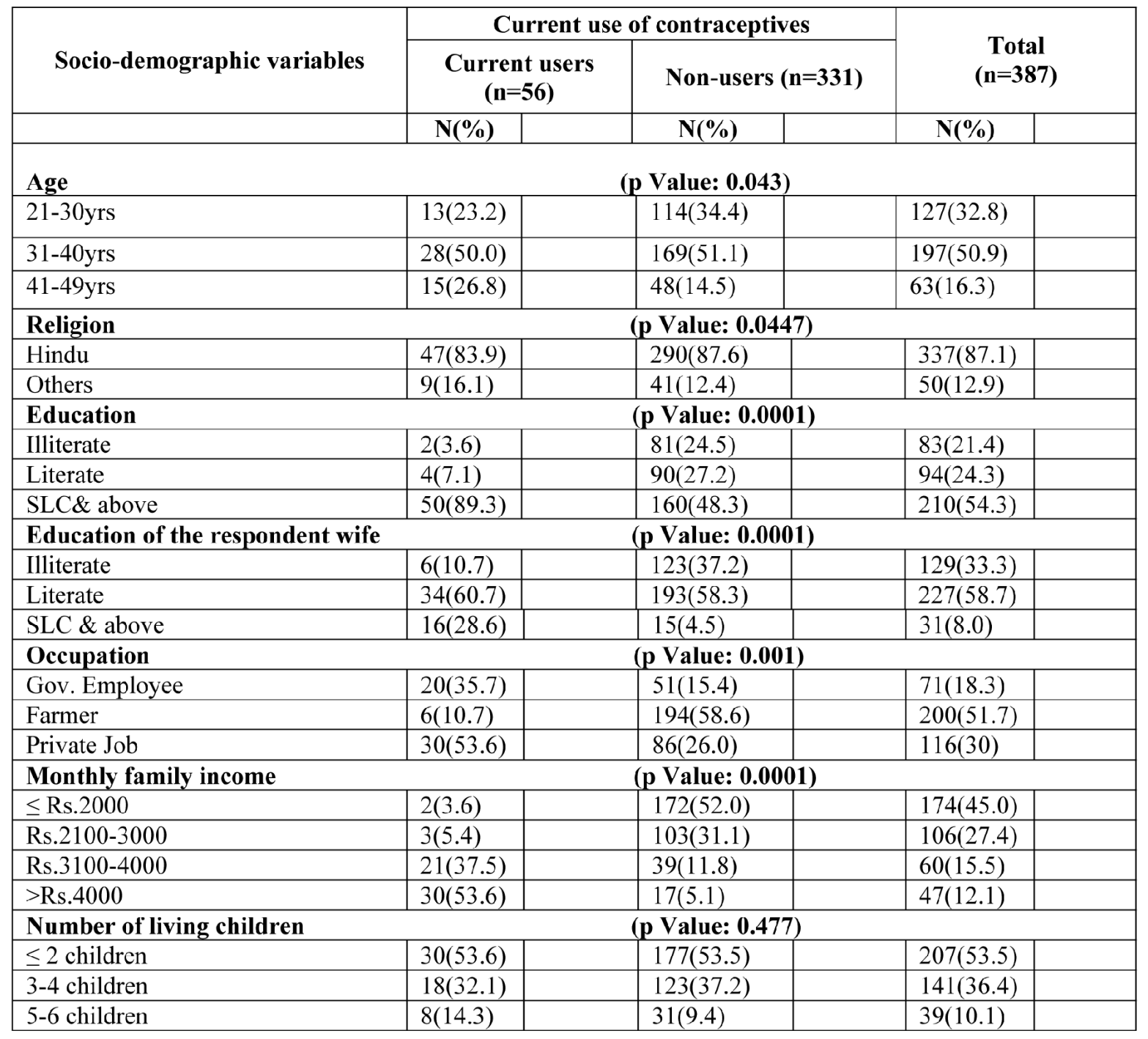




\section{Discussion}

Socio-demographic characteristics: In this finding, the mean age of the study population is 33.48 years with standard deviation 6.164. The age of the respondents varies from 21 to 49 years. Almost half of the respondents between 31-40 years age group were currently using any contraceptive method. The chi square test showed significance $(\mathrm{p}<0.05)$ between age of respondents and use of contraception. It indicates the fact that practice of contraceptive method was higher in age 31- 40 years because they want to limit their family size.

Majority of the respondents following Hindu religion were using contraceptives. There was no significant $(p>0.05)$ relationship between religion and the use of contraceptives.

It is found that uses of contraceptive method rise along with the educational status of the respondents. Higher the educational level, higher the use of contraceptive methods. Chi-square test indicates the relationship between education and use of contraceptive to be significant $(\mathrm{p}<0.01)$. Similar study from Nigeria showed that currently use of any family planning methods were likely to be men with high formal education. ${ }^{11}$ Similarly, if we cross tabulate the educational attainment of respondents' wives and use of contraceptives, it can be reported that there is significant $(p<0.001)$ relationship between these two variables.

Most of the respondents who are engaged in private job as well as business were using contraceptives. The chi-square test $(p<0.001)$ reflects that there is strong relationship between the occupation and the use of contraception. This study also shows wide variation in contraceptive uses across occupational line which is similar to the other studies. ${ }^{12}$

In our study, very few respondents with low income status used contraceptives. This also shows that higher the income status, higher the use of contraceptives.

It indicates a strong relationship $(\mathrm{p}<0.001)$ between poverty and use of contraceptives. Similar strong link between use of contraceptives and level of economic status were observed by Mugni P. ${ }^{13}$

The respondents who have higher number of children are less likely to use a contraceptive compared to the respondents with fewer number of children. The chi-square test $(p>0.05)$ suggests that there is no significant difference between user of contraceptive and number of children.

Responsible for contraception: Among the respondents $216(55.8 \%)$ mentioned that responsibility for contraception should be shared by both of spouse. The result shows that majority of the respondents wants to share responsibility. In their study Islami $\mathrm{S}$, Med has mentioned $64 \%$ of men approved the use of contraceptives, which is also similar to this study. ${ }^{14}$

Currently using the contraceptive methods: Out of 387 respondents, only 56(14.5\%) respondents were using condoms and vasectomy for contraception in practical life, which is little far from the Nepal Demographic and Health Survey, 2002. ${ }^{15}$ According to the results, majority of the men $39(69.6 \%)$ had vasectomy while $17(30.4 \%)$ were using condoms for contraception. The results show that vasectomy is popular. Basically, condom is one of the safest contraceptive methods and can prevent sexually transmitted diseases as well. $187(48.3 \%)$ respondents had used contraceptives but 144 (37\%) had never used them. This result shows condom to be the commonly used contraceptive method. Mostly respondents collected contraceptive methods from Government hospital and health center because they provide contraceptive methods with incentives and without cost.

Reasons for not using the contraceptive: The results from the survey reflect that men are not using contraceptive methods because it interferes with sexual satisfaction as well as there is no option except condom or vasectomy. Overall, these data suggest that there is substantial scope for family planning program to increase contraceptive use by providing advocacy and alternative methods. Stepped up information and education activities will play an important role for dispelling fears and misconceptions about specific methods of contraception and contraceptive use in general.

Knowledge about contraceptive methods: Acquiring knowledge of contraceptive is an important precondition towards gaining access to and then using a suitable contraceptive method. The capability to name and highlighting some advantage and disadvantage is a trial of respondent's knowledge. $34.1 \%$ of the respondents have poor knowledge that they mentioned at least 2-3 names of contraceptive methods spontaneously. Majority $50.9 \%$ of the respondents have moderate knowledge. Similarly, $15 \%$ of the respondents had good knowledge that they mentioned names, advantages and disadvantages of the contraceptive methods. Among the respondents having good knowledge, $62.2 \%$ were using contraceptive methods. Similarly, among the respondents with moderate-knowledge, $30.4 \%$ were using contraceptive methods and among poorknowledge respondents $7.1 \%$ were using them. It is by the test found that $p<0.001$, which indicate that there is strong association between knowledge and use of contraceptive methods. In his study, Mugni $\mathrm{P}$ also mentioned that there is 
strong relation between knowledge and the use of contraceptives. ${ }^{13}$

\section{Conclusions}

It can be concluded that although almost all respondents knew about at least one contraceptive method, only $15 \%$ of the respondents had adequate knowledge and there was strong association between knowledge and the use of contraceptive methods.

Almost majority agree that the responsibility for contraception should be shared by both husband and wife, but use of contraceptive methods among men is still low. The main reason for men lagging behind could be that the burden of contraception in a family is taken up by females. Other reasons could be non-availability of alternative methods and lack of adequate knowledge. Most of those using contraceptives collected them from government hospitals and private pharmacies. Though most men had positive attitude, current users of contraceptive methods were likely to be men with formal education and good economic condition.

\section{References}

1. United Nation (UN). World Contraceptive Use 2007. New York: UN Department of Economic and Social Affairs, Population Division; 2008. Available from: URL:www.un.org/esa/population/publications/ contraceptives2007/contraceptives2007.htm.

2. United Nation (UN). World Contraceptive Use. New York: UN Department of Economic and Social Affairs, Population Division; 1996.

3. Levine R, Langer A, Birdsall N, Matheny G, Wright M, Bayer A. Contraception. In: Jamison DT, Breman JG, Measham AR, et al. eds. Disease control priorities in developing countries. New York: Oxford University Press; 2006. p. 1075-90. Available from: URL:www. dcp2.org/pubs/DCP/57/

4. Singh S, Darroch JE, Vlassof M, Nadeau J. Adding it up: the benefit of investing in sexual and reproductive health care. New York: Alan Guttmacher Institute; 2003. Available from: URL:www. guttmacher.org/pubs/ addingitup.pdf.

5. World Health Organization (WHO). Unsafe abortion: global and regional estimates of the incidence of unsafe abortion and associated mortality in 2000 . Geneva: WHO; 2004. Available from: URL:http:// www.who.int/reproductivehealth/publications/ unsafe abortion/9241591803/en/index.html

6. United Nation Fund for Population Activities (UNFPA). The state of world population, the right to choose reproductive right and reproductive health. New York: UNFPA; 1997.p. 76.

7. International Conference on Population and Development (ICPD). Report of the International Conference on Population and Development, Cairo. New York: United Nations Development Program; 1994.

8. Department of Health Services. Annual report. Kathmandu, Nepal: Department of Health Services, Ministry of Health; 2004.

9. Park K. Park's textbook of preventive and social medicine. 18th ed. Jabalpur, India: M/S Banarasidas, Bhanot Publishers; 2004. p. 405.

10. www.moh.gov.np

11. Lawoyin TO, Osinowo H, Babatunde M, Bajomo TG, Betiku AO Biakolo, Busari KT, et al. A family planning in rural Nigeria: a study among men. Afr J Med Med Sci. 2002;31(2):159-62.

12. Posner JK, Mbodji F. Men's attitudes about family planning in Dakar, Senegal. Int Fam Plan Perspect. 1989;21(3):279-91.

13. Mungai P. Men's knowledge, attitudes and practices with regard to family planning. Afr Link. 1996 Apr:5-7.

14. Ismail S. Men's knowledge, attitude and practices of family planning in north Gondar. Ethiop Med J. 1998 Oct;36(4):261-71.

15. Ministry of Health and Population, New ERA and Macro International Inc. Nepal demographic and health survey 2006: key findings. Kathmandu, Nepal, and Calverton, Maryland, USA: Ministry of Health and Population, New ERA and Macro International Inc; 2007. p. 5-6. 